$c$, ditto, from a French specimen received from Monsieur Eugène Simon.

Fig. 3. Drassus criminalis, sp. n., 오 : $a$, spider, without legs, enlarged; $b$, ditto, in profile; $c$, eyes, from the front; $d$, genital aperture; $e$, natural length of spider.

Fig. 4. Drassus delinquens, sp. n.: $a$, spider (without legs), enlarged; $b$, profile; $c$, eyes, from the front ; $d$, genital aperture; $e$, natural length of spider.

Fig. 5. Erigone Douglasi, sp. n. : a, profile of spider (without legs), enlarged; $b$, spider, from above, without legs; $c$, eyes and falces, from the front; $d$, genital aperture.

Fig. 6. Erigone nigriceps, sp. n.: $a$, spider, in profile (without legs) enlarged; $b$, ey€s and falces, from the front; $c$, genital aperture; $d$, natural length of spider.

Fig. 7. Erigone subitanea, sp. n.: $a$, spider in profile (with legs truncated) enlarged; $b$, eyes and falces, from the front; $c$, left palpus, inner side in front; $d$, left palpus, in front, rather on outer side ; $e$, natural length of spider.

Fig. 8. Limyphia aëria, sp. n.: a, spider, in profile (without legs), enlarged; $b$, eyes, from the front; $c$, abdomen, in profile; $d$, right palpus, outer side (inverted); $e$, natural length of spider.

Fig. 9. Lycosa arenicola, sp. n. : $a$, digital joint of $\delta$, showing structure of palpal organs; $a-x$, characteristic oblique process of ditto; $b$, genital aperture of $q$.

Fig. 10. Lycosa annulata, Thorell : $a$, digital joint of $\delta^{*}$, showing palpal organs; $a-x$, characteristic obtuse tuberculiform process of ditto; $b$, genital aperture of $q$.

Fig. 11. Lycosa riparia, C. Koch: digital joint of $\delta$, showing palpal organs; $x$, characteristic oblique spine ; $y$, slender adjacent spine.

Fg. 12. Lycosa prativaga, L. Koch : a, digital joint of $\delta$, showing palpal organs; $a-x$, characteristic oblique spine; $a-y$, slender spine adjacent ; $b$, genital aperture of $q$ (from a German example received from Dr. Ludwig Koch).

XXXII.-Descriptions of new Species of Vespertilionidæ. By G. E. Dobson, M.A., M.B., F.L.S., \&c.

\title{
Genus Vespertilio.
}

Vespertilio, Keys. \& Blas. Wiegm. Archiv, 1839, p. 304.

a. Feet moderate; wings to the base of the toes. (Subg. Vespertilio.)

Vespertilio africanus, n. subsp.

Ears shorter than the head; laid forwards the tips do not reach to the end of the muzzle; tragus acutely pointed. Glands on the side of the muzzle forming a conspicuous rounded elevation on either side between the eye and nostril.

Fur above dark at the base, with greyish extremities; 
beneath, the basal half of the hairs is dark, the terminal half white.

Length (of an adult male preserved in alcohol)-head and body 2.5 inches, tail $2 \cdot 3$, head 0.9 , ear 0.85 , tragus $0.4 \times 0.1$, forearm $2 \cdot 2$, thumb $0 \cdot 45$, second finger $3 \cdot 7$, fourth finger 3 , tibia $1 \cdot 05$, foot and claws $0 \cdot 45$.

Hab. Gaboon, W. Africa.

This species belongs to the same section of Vespertilio as $V$. murinus of Europe, which it very closely resembles in general form, in size, and even in the colour of the fur. It is, however, at once distinguished by the much shorter ears, acutely pointed tragus, and great development of the glands of the muzzle. The wing-membrane also does not extend so far outwards along the foot as in V. murinus, and the inner side of the ear-conch is less hairy.

Though thus readily distinguished from $V$. murinus of Europe, I am induced, on account of its very close general affinities to that species, to consider it a subspecies only.

Type in the collection of the British Museum.

b. Feet very large; wings to the ankles or tarsus. (Subg. Leuconö̈.)

Vespertilio megalopus, n. sp.

Very similar to $V$. Daubentonii; but the ears are longer, much narrower and more acute, and, laid forwards, the tips pass beyond the end of the nose at least one tenth of an inch; the inner margin, instead of forming a regular arc from the base to the tip, is flattened along the upper third, and the narrow extremity of the ear is sharply rounded off. The tragus is also longer and narrower, and the upper third of the inner margin is slightly concave; but the extremity is not directed inwards.

The wing-membrane does not extend so far down on the tarsus as in V. Daubentonii ; and the second upper premolar is slightly drawn inwards. In other respects, in general form and in the colour and distribution of the fur, this species closely resembles $V$. Daubentonii, of which it may be considered the African representative.

Length (of a male specimen preserved in alcohol)-head and body $1 \cdot 65$ inch, tail $1 \cdot 6$, head $0 \cdot 6$, ear $0 \cdot 55$, tragus $0 \cdot 3$, forearm $1 \cdot 45$, thumb $0 \cdot 35$, second finger $2 \cdot 3$, fourth finger $1 \cdot 9$, tibia $0 \cdot 6$, foot and claws $0 \cdot 4$.

Hab. Gaboon. Type in the collection of the British Museum. 


\section{Genus Vesperugo.}

Vesperugo, Keys. \& Blas. Wiegm. Archiv, 1839, p. 312.

\section{Vesperugo (Vesperus) platyrhinus, n. sp.}

Muzzle broad and obtuse; glandular prominences large, smoothly rounded; nostrils opening near the margin of the upper lip, on a level with the rounded extremity of the muzzle, not emarginate between. The front of the muzzle is evenly bevelled off from the summit of the glandular elevations to the margin of the upper lip; and the nasal apertures are narrow, appearing as small oblique slits in the front of the muzzle. Ears and tragus as in V. Kuhlii.

Wings from the base of the toes; postcalcaneal lobe small, but distinct; last caudal vertebra half free.

Fur above dark brown, paler towards the tip; beneath similar, the extremities of a lighter colour than on the upper surface.

Upper inner incisors long, faintly bifid at the extremities; outer incisors very short, scarcely equalling the cingulum of the inner ones; lower incisors crowded, trifid; no minute upper premolar; the single upper premolar very close to the canine.

Length (of an aduit male)-head and body 1.8 inch, tail $1 \cdot 4$, head $0 \cdot 7$, ear 0.55 , tragus $0 \cdot 25$, forearm $1 \cdot 35$, second finger $2 \cdot 15$, fourth finger $1 \cdot 65$, tibia $0 \cdot 45$, foot $0 \cdot 25$.

Hab. Unknown. Type in the collection of the British Museum.

This very peculiar species of Vesperugo resembles $V$. Kuhlii in size and in general form; but the absence of the first minute upper premolar and the shape of the muzzle at once distinguish it. The shape of the muzzle is so peculiar as to lead me to suspect it may be an individual peculiarity. As the specimen from which the description is taken is well preserved in alcohol, this flattening of the front of the muzzle and extremities of the nostrils is not due to imperfect preservation.

XXXIII.-Descriptions of new Species of Geckotidæ in the British-Museum Collection. By A. W. E. O'Shaughnessy, Assistant in the Departments of Natural History.

\section{Phyllodactylus tuberculosus,}

described by Wiegmann (Acta Ac. Nat. Curios. xvii. p. 241, pl. 18. fig. 2) from California, to which we must add as a synonym the Phyllodactylus Xanti described by Cope 


\section{$2 \mathrm{BHL}$ Biodiversity Heritage Library}

Dobson, G. E. 1875. "XXXII.—Descriptions of new species of Vespertilionidæ." The Annals and magazine of natural history; zoology, botany, and geology 16, 260-262. https://doi.org/10.1080/00222937508681167.

View This Item Online: https://www.biodiversitylibrary.org/item/81071

DOI: https://doi.org/10.1080/00222937508681167

Permalink: https://www.biodiversitylibrary.org/partpdf/62955

\section{Holding Institution}

Smithsonian Libraries

\section{Sponsored by}

Smithsonian

\section{Copyright \& Reuse}

Copyright Status: Public domain. The BHL considers that this work is no longer under copyright protection.

This document was created from content at the Biodiversity Heritage Library, the world's largest open access digital library for biodiversity literature and archives. Visit BHL at https://www.biodiversitylibrary.org. 